\title{
Comparison of the Binding Modes of $\left[\mathrm{Ru}\left(2,2^{\prime} \text {-bipyridine }\right)_{3}\right]^{2+}$ and $\left[R u\left(2,2^{\prime}: 6^{\prime}, 2^{\prime \prime} \text {-terpyridine }\right)_{2}\right]^{2+}$ to Native DNA
}

\author{
Yoon Jung Jang, Hyun Mee Lee, Kyeung Joo Jang, Jae-Cheol Lee, ${ }^{\dagger}$ Seog K. Kim, and Tae-Sub Cho* \\ Department of Chemistry, College Science, Yeungnam University, Gyeong-buk 712-749, Korea. *E-mail: tscho@yu.ac.kr \\ Received January 19, 2010, Accepted March 16, 2010
}

\begin{abstract}
The $\left[\mathrm{Ru}(\text { tpy })_{2}\right] \mathrm{Cl}_{2}$ (tpy:2,2':6',2"-terpyridine) complex was synthesized and its structure was confirmed by ${ }^{1} \mathrm{H}-\mathrm{NMR}$ and elemental analysis. Its binding mode toward DNA was compared with the well-known $\left[\mathrm{Ru}(\mathrm{bpy})_{3}\right] \mathrm{Cl}_{2}(\mathrm{bpy}: 2,2-$ bipyridyl), using isotropic absorption, linear dichroism(LD) spectroscopy, and an energy minimization study. Compared to $\left[\mathrm{Ru}(\mathrm{bpy})_{3}\right]^{2+}$, the $\left[\mathrm{Ru}(\mathrm{tpy})_{2}\right]^{2+}$ complex exhibited very little change in its absorption pattern, especially in the MLCT band, upon binding to DNA. Furthermore, upon DNA binding, both Ru(II) complexes induced a decrease in the LD magnitude in the DNA absorption region. The $\left[\mathrm{Ru}(\mathrm{tpy})_{2}\right]^{2+}$ complex produced a strong positive LD signal in the ligand absorption region, which is in contrast with the $\left[\mathrm{Ru}(\mathrm{bpy})_{3}\right]^{2+}$ complex. Observed spectral properties led to the conclusion that the interaction between the ligands and DNA bases is negligible for the $\left[\mathrm{Ru}(\mathrm{tpy})_{2}\right]^{2+}$ complex, although it formed an adduct with DNA. This conclusion implies that both complexes bind to the surface of DNA, most likely to negatively charged phosphate groups via a simple electrostatic interaction, thereby orienting to exhibit the LD signal. The energy minimization calculation also supported this conclusion.
\end{abstract}

Key Words: Ru(II) complex, Binding mode, DNA, Light Switch Effect, Polarized spectroscopy

\section{Introduction}

During the past decade, the interaction of metal complexes with DNA has attracted much attention for application as probes of DNA structure and in the development of new therapeutic regents. ${ }^{1}$ The $\mathrm{Ru}(\mathrm{II})$ polypyridyl-type complexes containing planar aromatic ligands and DNAs are of particular interest for the well-known light switch effect, stability upon binding to DNA, possibility of recognition of DNA helicity, role as an electron acceptor in DNA-mediated electron transfer, and photoinduced DNA cleavage. ${ }^{2-6}$ Recently developed new techniques, including the density functional theory method, picosecond time-resolved resonance Raman spectroscopy, and femtosecond linear dichroism have also been applied to investigate the nature of interactions, including the strength, geometries, and modes of Ru(II) complexes with DNA. ${ }^{7-14}$ In general, Ru(II)-polypyridyl complexes bind to DNA in a non-covalent interaction fashion. The known modes of binding of the $\mathrm{Ru}(\mathrm{II})$-polypyridyl complex to DNA include electrostatic binding at the surface of DNA, groove binding, ${ }^{15}$ and intercalative binding, which is subsequentially categorized as classical intercalation, semi-intercalation, and quasi-intercalation. ${ }^{7,16}$

The interesting chemistry of $\left[\operatorname{Ru}\left(2,2^{\prime} \text {-bipyridine) }\right)_{3}\right]^{2+}$ (hereafter referred to as $\left.\left[\mathrm{Ru}(\mathrm{bpy})_{3}\right]^{2+}\right)$ has stimulated the preparation and characterization of many related new octahedral $\mathrm{Ru}(\mathrm{II})$ polypyridyl complexes in order to explicate the effects of ligand structure on ground- and excited-state redox, photochemical, and photophysical properities. ${ }^{17-25}$ Development of new DNA structural probes and potential new chemotherapeutic agents has also been an important motivation of $\left[\mathrm{Ru}(\mathrm{bpy})_{3}\right]^{2+}$-related complex studies. ${ }^{26-31}$ Many important applications of these complexes require that the complex binds to DNA through an intercalative mode. The planarity of the ligand is thought to play a key role in the binding mode and affinity. ${ }^{7,32}$ The nature of the ancillary ligand can indirectly affect DNA binding properties through changing the planarity of the main ligand and hydrophobicity of the complex. ${ }^{33,34}$ All these studies indicate that a subtle change in the molecular structure may exert significant effects on binding modes, locations, and affinities and provide a chance to explore varied and valuable information regarding conformation- or site-specific DNA probes. However, investigations of Ru(II)-polypyridyl complexes with tridentate ligands have attracted much less attention and their vast potential as DNA-binding reagents remains largely untapped.

In this work, the binding mode of $\left[\mathrm{Ru}\left(2,2^{\prime}: 6^{\prime}, 2^{\prime \prime}\right.\right.$-terpyridine $\left.)_{2}\right]^{2+}\left(\right.$ hereafter referred to as $\left[\mathrm{Ru}\left(\mathrm{tpyy}_{2}\right]^{2+}\right)$ to DNA was compared with that of the well-known $\left[\mathrm{Ru}(\mathrm{bpy})_{3}\right]^{2+}$ complex. The latter complex possesses three symmetric planar bidentate ligands, while the former contains tridentate ligands (Scheme 1). Comparison of these two $\mathrm{Ru}$ (II) complexes potentially enables investigation into the role of ligand planarity, or effects of ligand steric hindrance, in the formation of the adduct between the $\mathrm{Ru}(\mathrm{II})$ complex and DNA.
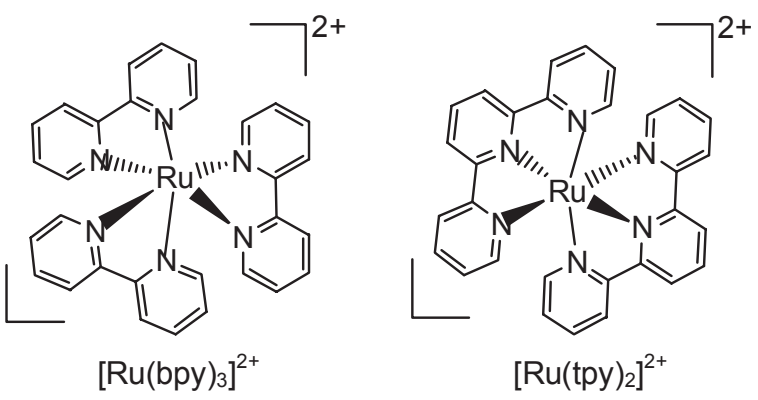

Scheme 1. Molecular structures of the $\left[\operatorname{Ru}(b p y)_{3}\right]^{2+}$ and $\left[R u(t p y)_{2}\right]^{2+}$ complexes. 


\section{Experimental Section}

Materials. Calf thymus DNA (referred to as DNA) was purchased from Worthington (Lakewood, NJ, USA) and purified by dissolution (exhaustive shaking at $4{ }^{\circ} \mathrm{C}$ ) in $5.0 \mathrm{mM}$ cacodylate buffer ( $\mathrm{pH} 7.0$ ) containing $100 \mathrm{mM} \mathrm{NaCl}$ and $1.0 \mathrm{mM}$ EDTA, followed by several rounds of dialysis at $4{ }^{\circ} \mathrm{C}$ against $5.0 \mathrm{mM}$ cacodylate buffer ( $\mathrm{pH}$ 7.0). The latter buffer was used throughout this work. The mixing ratio $(R)$ was defined by the ratio of the concentration of the loaded drug per DNA base or phosphate concentration. The $\left[\mathrm{Ru}(\mathrm{bpy})_{3}\right]^{2+, 35,36}$ and $\left[\mathrm{Ru}(\mathrm{tpy})_{2}\right]^{2+, 37}$ complexes were prepared accordingly to reported methods. The concentrations of DNA, $\left[\mathrm{Ru}(\mathrm{bpy})_{3}\right]^{2+}$, and $\left[\mathrm{Ru}(\mathrm{tpy})_{2}\right]^{2+}$ were determined spectrophotometrically using their respective extinction coefficients: $\varepsilon_{258 \mathrm{~nm}}=6700 \mathrm{M}^{-1} \mathrm{~cm}^{-1} ; \varepsilon_{452 \mathrm{~nm}}=14600 \mathrm{M}^{-1}$ $\mathrm{cm}^{-1} ; \varepsilon_{475 \mathrm{~nm}}=12570 \mathrm{M}^{-1} \mathrm{~cm}^{-1}$. Other chemicals were purchased from Sigma-Aldrich (St. Louis, MO, USA) or Merck (Whitehouse. NJ, USA) and used without purification.

Measurements. Absorption spectra were recorded on a Cary 100 (Varian, Australia). Linear dichroism spectra (referred to as LD) were measured on a J810 (Jasco, Tokyo, Japan) spectropolarimeter. $\mathrm{LD}$ is defined by the difference in absorbance for the light polarized parallel and perpendicular to the orientation axis of the chromophore. A Wada-type inner-rotating flow cell ${ }^{38}$ was used to align the DNA sample for LD measurements, as described by Nordén and coworkers. ${ }^{39-41}$ The division of the measured LD by isotropic absorption spectrum results in a dimensionless quantity denoted as reduced linear dichroism $\left(\mathrm{LD}^{\mathrm{r}}\right)$, which reflects the angle $(\alpha)$ of the transition moment of any DNA-bound drug with respect to the local DNA helical axis and the ability of the orientation of the DNA-drug adduct through $\mathrm{LD}^{\mathrm{r}}=1.5 \mathrm{~S}$ $\left(<3 \cos ^{2} \alpha>-1\right)$, where $S$ is the orientation factor, a measure of orientability.

Synthesis of $\left[\mathbf{R u}(\mathrm{bpy})_{3}\right]^{2+}$ and $\left[\operatorname{Ru}(\mathrm{tpy})_{2}\right]^{2+}$. The $\left[\mathrm{Ru}(\mathrm{bpy})_{3}\right]^{2+}$ and $\left[\mathrm{Ru}(\mathrm{tpy})_{2}\right]^{2+}$ complexes were synthesized by a previously reported method, and the structures were confirmed by comparing the elemental analysis and ${ }^{1} \mathrm{H}-\mathrm{NMR}$ data. ${ }^{35-37}$

$\left[\mathbf{R u}(\mathbf{b p y})_{3}\right] \cdot \mathbf{C l}_{2}$ : Light orange color Elemental analysis calcd (\%) for $\mathrm{C}_{30} \mathrm{H}_{24} \mathrm{~N}_{6} \mathrm{Cl}_{2} \mathrm{Ru}$ (640.5358): C 56.3, H 3.8, N 13.1; Found: C 56.0, H 3.6, N 12.5, ${ }^{1} \mathrm{H}-\mathrm{NMR}\left(\left[\mathrm{Ru}(\mathrm{bpy})_{3}\right] \cdot \mathrm{Cl}_{2}, 600 \mathrm{MHz}\right.$, DMSO- $\left.d_{6}, 25^{\circ} \mathrm{C}\right) \delta 8.72(\mathrm{dd}, 6 \mathrm{H}), 8.49(\mathrm{dd}, 6 \mathrm{H}), 7.84(\mathrm{~m}, 6 \mathrm{H})$, $7.32(\mathrm{~m}, 6 \mathrm{H})$.

[Ru(tpy) $)_{2} \cdot \cdot \mathbf{C l}_{\mathbf{2}}$ : Light red color Elemental analysis calcd (\%) for $\mathrm{C}_{30} \mathrm{H}_{22} \mathrm{~N}_{6} \mathrm{Cl}_{2} \mathrm{Ru}$ (638.52): C 56.4, $\mathrm{H}$ 3.5, N 13.2; Found: $\mathrm{C}$ 56.6, H 3.7, N 13.5, ${ }^{1} \mathrm{H}-\mathrm{NMR}\left(\left[\mathrm{Ru}(\mathrm{tpy})_{2}\right] \cdot \mathrm{Cl}_{2}, 600 \mathrm{MHz}\right.$, DMSO- $\left.d_{6}, 25{ }^{\circ} \mathrm{C}\right) \delta 9.09(\mathrm{~d}, 2 \mathrm{H}), 8.82(\mathrm{~d}, 4 \mathrm{H}), 8.59(\mathrm{t}, 2 \mathrm{H})$, 8.08 (dd, 4H), 7.72 (d, 4H), 7.34 (dd, 4H).

Molecular modeling. Energy minimization calculations were performed by Gaussian 03 software, using the density functional theory with the LANL2DZ basis set for the probable structure of the Ru(II) complex-DNA adducts. The double-stranded oligonucleotide $[\mathrm{d}(\mathrm{ATGCATGCAT})]_{2}$ was used for the modeling. The structures of the decamer and DNA-ligand complexes were constructed with the nucleic acids in the Hyperchem 7.0 program. In order to neutralize the duplex, $18 \mathrm{Na}^{+}$ions were added and solvated with explicit water. The size of the periodic box and number of waters was $30 \AA \times 25 \AA \times 35 \AA$ and $867 \sim 1012$, respectively. The electrostatic potential calculation used distance- dependent dielectrics with a scale factor of four. Energy minimizations were carried out using the AMBER force field implemented in the Hyperchem 7.0 program by the conjugate gradient method. The optimized structures were carried out on an IBM p690 system located in the supercomputer center of the Korea Institute of Science and Technology Information (KISTI). All energy minimizations were performed on a personal computer.

\section{Results and Discussion}

Absorption spectrum and association of the $\mathrm{Ru}$ (II) complexes with DNA. The binding of any drug to DNA generally manifests itself by a hypochromism and red-shift in the drug absorption region. In the classical intercalator case, these changes in the absorption spectrum originate mainly from the $\pi-\pi$ stacking between the fused aromatic hydrocarbons of the planar intercalator and the DNA bases. The red-shift and hypochromism for the minor groove binding drugs are usually assigned to the conformational change of the drug upon fitting in the narrow minor groove. Figure 1(a) depicts the absorption spectrum of the $[\mathrm{Ru}$ (bpy $\left.)_{3}\right]^{2+}$ complex in the presence and absence of DNA. In the absence of DNA, the $\left[\mathrm{Ru}(\mathrm{bpy})_{3}\right]^{2+}$ complex produced large ab-

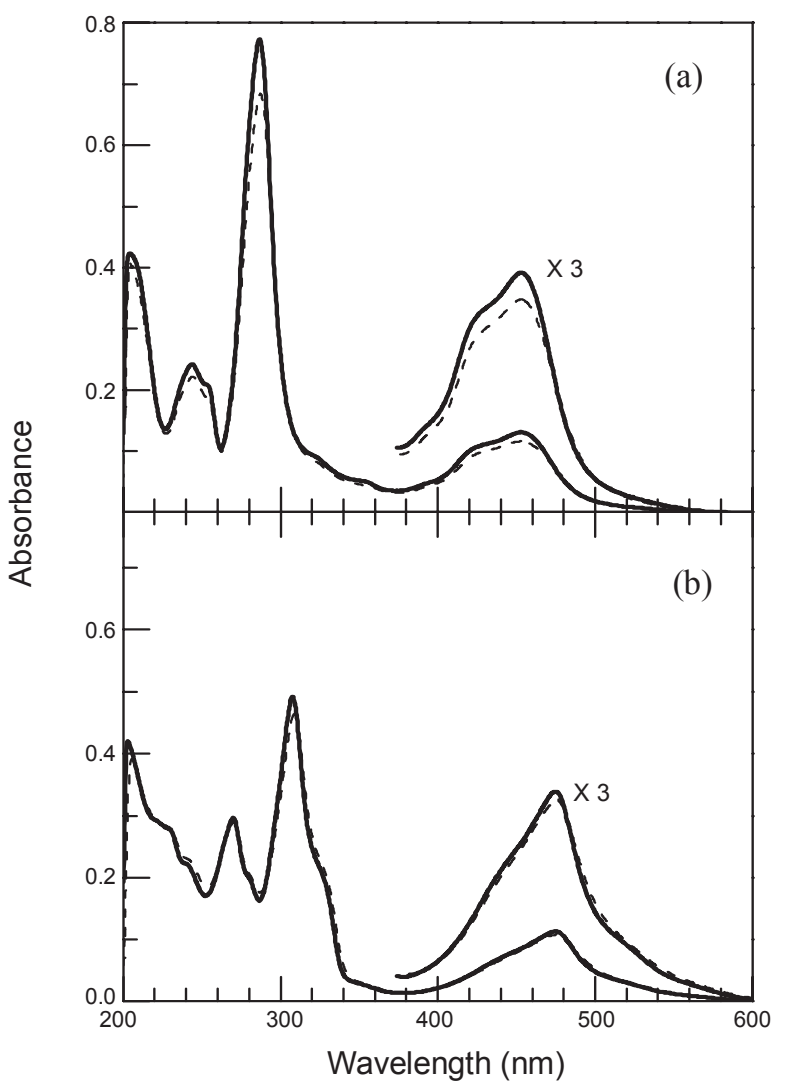

Figure 1. Absorption spectrum of the $\left[\mathrm{Ru}(\mathrm{bpy})_{3}\right]^{2+}$ (panel a) and $[\mathrm{Ru}$ $\left.(\text { tpy })_{2}\right]^{2+}$ (panel b) complex in the presence (dotted curve) and absence (solid curve) of DNA. [DNA] $=100 \mu \mathrm{M}$, $[\mathrm{Ru}(\mathrm{II})$ complex $]=2,4,6,8$, and $10 \mu \mathrm{M}$. Absorption spectrum of Ru(II) complex-free DNA was subtracted from that of the adduct for ease of comparison. Absorption spectrum at various $\mathrm{Ru}(\mathrm{II})$ complex concentrations was identical when normalized to concentration, hence, only one spectrum for the 10 $\mu \mathrm{M} \mathrm{Ru}(\mathrm{II})$ complex is shown. 
sorption bands in the DNA absorption region at 244 and $286 \mathrm{~nm}$, with a shoulder near $254 \mathrm{~nm}$. These absorption bands reflect the intra-ligand electric transitions that may lie parallel and perpendicular to the molecular $\mathrm{C}-\mathrm{C}$ axis, connecting the two pyridine rings. Small absorption bands at 322 and $353 \mathrm{~nm}$, likely from the same origin, were also apparent. The absorption band in the long wavelength region, consisting of two maxima at 423 and 452 $\mathrm{nm}$, belongs to the metal-to-ligand charge transfer (MLCT) band. Absorption spectra of the $\left[\mathrm{Ru}(\mathrm{bpy})_{3}\right]^{2+}$ complex in the presence of DNA were recorded at [complex]:[DNA base] ratios of $0.02,0.04,0.08$, and 0.10 , with a fixed DNA concentration $(100 \mu \mathrm{M})$. When the DNA absorption spectrum was subtracted from those of the adducts, and normalized to the concentration, the appearance of the absorption spectrum of the adduct were identical. This observation suggested that the binding mode of the $\left[\mathrm{Ru}(\mathrm{bpy})_{3}\right]^{2+}$ complex to DNA was homogeneous in the concentration range adopted in this work. If more than two binding modes exist, the absorption spectrum should vary unless the shape of the absorption spectrum representing the two different DNA-bound $\left[\mathrm{Ru}(\mathrm{bpy})_{3}\right]^{2+}$ species are coincidently identical. Observed hypochromism $(\sim 12 \%)$ at $286 \mathrm{~nm}$ in the DNA absorption region reflects an alteration in absorbance due to either changes in the DNA conformation, changes in the environment of the $[\mathrm{Ru}$ $\left.(\text { bpy })_{3}\right]^{2+}$ complex, or both. At this stage, these reasons cannot be distinguished and therefore, will not be discussed any further. Upon association with DNA, the $\left[\mathrm{Ru}(\mathrm{bpy})_{3}\right]^{2+}$ complex produced hypochromism $(\sim 12 \%)$ and a very small red-shift (from 452 to $453 \mathrm{~nm}$ ) in the visible wavelength region. This observation indicated with certainty that the MLCT electric transitions interact with those of the DNA bases, and therefore the $\left[\mathrm{Ru}(\mathrm{bpy})_{3}\right]^{2+}$ complex binds the DNA. The $\left[\mathrm{Ru}(\mathrm{tpy})_{2}\right]^{2+}$ complex produced an absorption spectrum consisting of an absorption maxima at 269, 307, and $475 \mathrm{~nm}$, with shoulders near 280, 325, and $443 \mathrm{~nm}$ in the absence of DNA. The former two maxima conceivably reflect the intra-ligand absorption, while the latter reflects the MLCT band (Fig. 1(b)). In contrast with the $\left[\mathrm{Ru}(\mathrm{bpy})_{3}\right]^{2+}$ complex, the $\left[\mathrm{Ru}(\mathrm{tpy})_{2}\right]^{2+}$ complex produced very small or almost insignificant changes in the absorption spectrum in the presence of DNA. This observation suggests that the interaction of the $\left[\mathrm{Ru}(\mathrm{tpy})_{2}\right]^{2+}$ complex with the DNA bases may be very small. However, as is evident from the LD measurements (see below), small changes in the absorption spectrum do not necessarily indicate that the $\left[\mathrm{Ru}(\mathrm{tpy})_{2}\right]^{2+}$ complex does not form any adduct with DNA.

LD and $L^{r}{ }^{r}$ spectra and the binding geometry. Figure 2 depicts the LD spectrum of the DNA and the adducts formed with the $\left[\mathrm{Ru}(\text { bpy })_{3}\right]^{2+}$ (panel a) and $\left[\mathrm{Ru}(\text { tpy })_{2}\right]^{2+}$ complexes (panel b). As expected from the set-up adopted in this work, the DNA produced a large negative LD band in its absorption region $(\sim 260$ $\mathrm{nm})$. Upon increasing the $\mathrm{Ru}(\mathrm{II})$ complex concentration, the magnitude of the LD gradually decreased, suggesting either a decrease in the ability of DNA to orient in the flow or a positive contribution of the DNA-bound Ru(II) complexes. The decrease in DNA orientability may be caused by various factors: partial dissociation of the double helix as a result of the drug binding; reduction in the repulsive interaction between the negatively charged phosphate groups through binding of positively charged drugs, potentially increasing DNA flexibility; bending at the

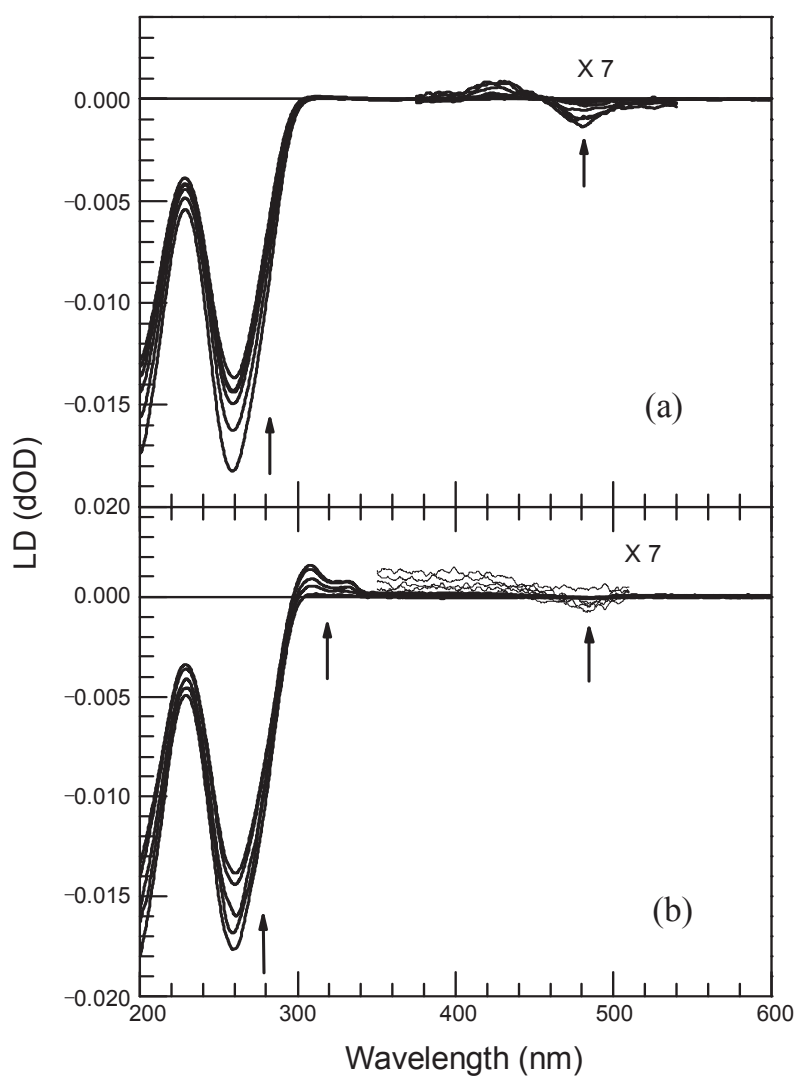

Figure 2. $\mathrm{LD}$ spectrum of the $\left[\mathrm{Ru}(\mathrm{bpy})_{3}\right]^{2+}$ (panel a) and $\left[\mathrm{Ru}(\text { tpy })_{2}\right]^{2+}$ (panel b) complex associated with DNA. [DNA] $=100 \mu \mathrm{M},[\mathrm{Ru}(\mathrm{II})$ complex $]=0,2,4,6,8$, and $10 \mu \mathrm{M}$ to the direction of arrows. The LD in the MLCT region was enlarged seven times.

drug binding site, which would reduce the contour length of DNA. In the current case, partial dissociation of double-stranded to single-stranded DNA does not seem to be the reason for the decrease in the LD magnitude because the partial dissociation near the drug binding site prevents orientation of the drug. As a result, there is a zero LD in the drug absorption region, which is not the case for the Ru(II) complex-DNA adduct. Small but clear LD signals in the MLCT absorption region were apparent for both $\mathrm{Ru}$ (II) complexes. For the same reason, the possibility of random binding at the surface of the DNA through the electrostatic attraction between the negatively charged phosphate groups of the DNA and the positively charged $\mathrm{Ru}(\mathrm{II})$ complexes can be also excluded.

A decrease in the $\mathrm{LD}^{\mathrm{r}}$ magnitude in the DNA absorption region, as a result of the decreased LD magnitude, was observed for both Ru(II) complex-DNA adducts (Fig. 3a and 3b, respectively, for the $\left[\mathrm{Ru}(\mathrm{bpy})_{3}\right]^{2+}$ and $\left[\mathrm{Ru}(\mathrm{tpy})_{2}\right]^{2+}$ complexes). The shape of the $\mathrm{LD}^{\mathrm{r}}$ spectrum was not identical in the presence and absence of the $\mathrm{Ru}$ (II) complex. The relatively wavelengthindependent LD $^{\mathrm{r}}$ magnitude between 240 and $290 \mathrm{~nm}$ (DNA base absorption region) was strongly tilted towards the positive direction. These observations suggest that the electric transition moments of both $\mathrm{Ru}(\mathrm{II})$ complexes in this wavelength region tilt with respect to the DNA helical axis. Three possible reasons for decreases in the $\mathrm{LD}^{\mathrm{r}}$ magnitude in the DNA absorption region, therefore, can be summarized as: tilt of the DNA stem by 


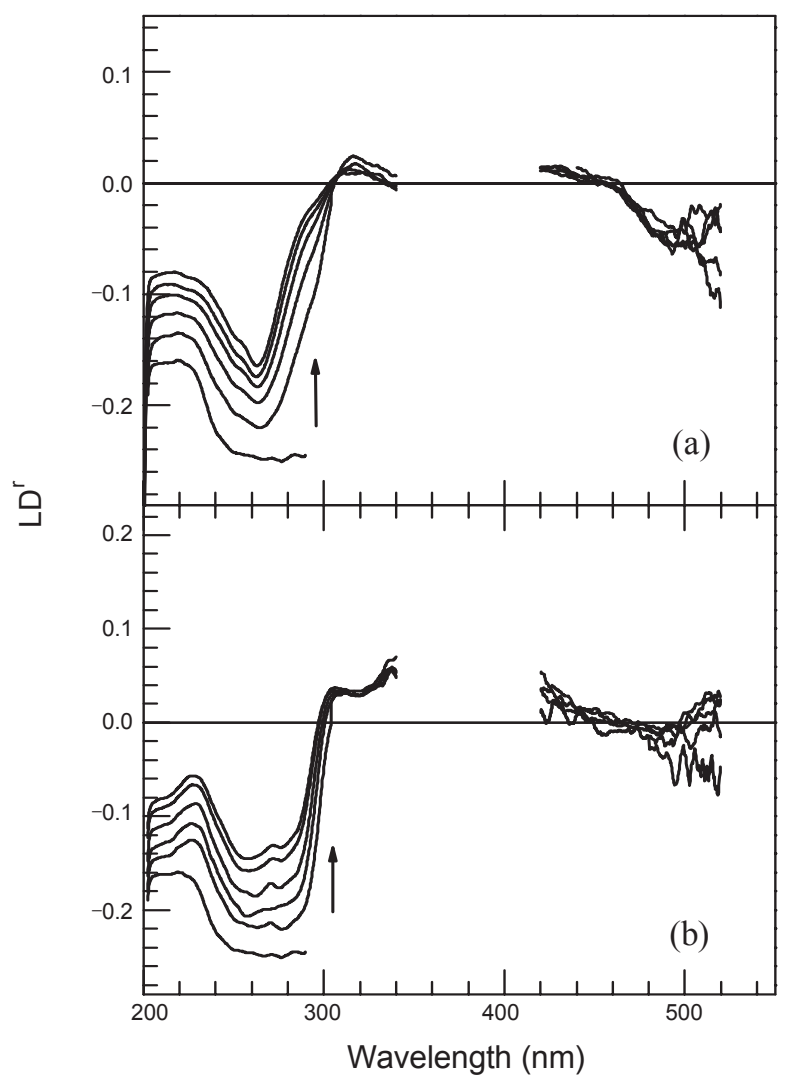

Figure 3. $\mathrm{LDr}$ spectrum of the $\left[\mathrm{Ru}(\mathrm{bpy})_{3}\right]^{2+}$ (panel a) and $\left[\mathrm{Ru}(\mathrm{tpy})_{2}\right]^{2+}$ (panel b) complex associated with DNA. The conditions and curve assignments are the same as in Fig. 2.

interaction with the $\mathrm{Ru}(\mathrm{II})$ complexes; increase in flexibility by reducing the repulsive electrostatic interaction between DNA phosphate groups as a result of binding of the $\mathrm{Ru}(\mathrm{II})$ complexes; positive contributions from the electric transition moments of the $\mathrm{Ru}(\mathrm{II})$ complexes. However, the extent of the contributions from these factors cannot be unambiguously determined at this stage. In the wavelength region between 300 and $340 \mathrm{~nm}$, where the authors contend that the intra-ligand electric transitions of the $\mathrm{Ru}(\mathrm{II})$ complexes absorb the radiation, the positive $\mathrm{LD}^{\mathrm{r}}$ signal was found for both $\mathrm{Ru}(\mathrm{II})$ complexes. The positive signal is clearer and larger for the $\left[\mathrm{Ru}(\text { tpy })_{2}\right]^{2+}$ complex than the $[\mathrm{Ru}$ $\left.(\text { bpy })_{3}\right]^{2+}$ complex. The positive $\mathrm{LD}^{\mathrm{r}}$ signal is generally accepted as an indication of a very strong tilt of the electric transitions with respect to the DNA helical axis. Therefore, it seems clear that any of the molecular planes of the ligand cannot be perpendicular to the DNA helical axis, and are thus parallel to the DNA base plane. In the MLCT region of longer wavelengths (above $420 \mathrm{~nm}$ ), the electric transition along the line connecting the metal atom and the center of the ligand is responsible for absorption of radiation. The apparent $\mathrm{LD}^{\mathrm{r}}$ spectrum of the both $\mathrm{Ru}(\mathrm{II})$ complex-DNA adduct is complicated and wavelengthdependent, reflecting the complication of the direction of the electric transitions of the $\mathrm{Ru}(\mathrm{II})$ complexes relative to the DNA helical axis. However, the $\left[\mathrm{Ru}(\mathrm{bpy})_{3}\right]^{2+}$ complex mainly exhibited a negative $\mathrm{LD}^{\mathrm{r}}$ in this region, while that of the $\left[\mathrm{Ru}(\mathrm{tpy})_{2}\right]^{2+}$ complex was positive. The extent of the variation in the $L D^{r}$

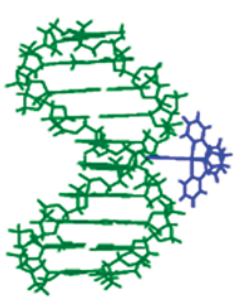

(a)

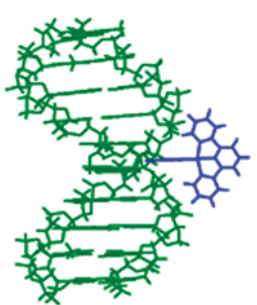

(d)

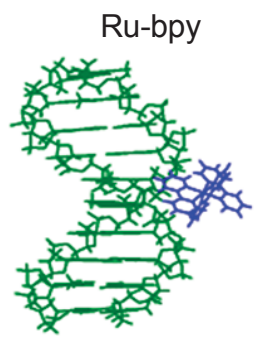

(b)

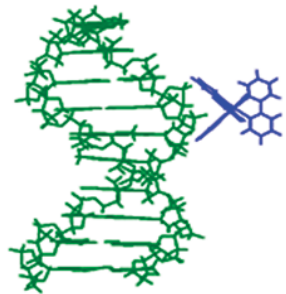

(c)

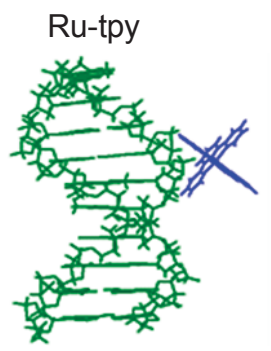

(e)

Figure 4. $\mathrm{LDr}$ spectrum of the $\left[\mathrm{Ru}(\mathrm{bpy})_{3}\right]^{2+}$ (panel a) and $\left[\mathrm{Ru}(\text { tpy })_{2}\right]^{2+}$ (panel b) complex associated with DNA. The conditions and curve assignments are the same as in Fig. 2.

magnitude was larger for the $\left[\mathrm{Ru}(\mathrm{bpy})_{3}\right]^{2+}$ complex. This observation suggested that an overall arrangement of the two $\mathrm{Ru}(\mathrm{II})$ complexes relative to the DNA was different.

Molecular modeling study. It is expected that the difference in molecular structure between the two $\mathrm{Ru}$ (II) complexes resulted in a different binding mode and interactions with DNA. Given from the experimental results that the $\left[\mathrm{Ru}(\mathrm{bpy})_{3}\right]^{2+}$ complex interacts with DNA bases more strongly compared to the $\left[\mathrm{Ru}(\mathrm{tpy})_{2}\right]^{2+}$ complex, and that none of the ligand molecular plane is perpendicular with respect to the DNA helical axis, various possible binding modes can be constructed. The energies of these structures were calculated, with three binding modes are possible for the $\left[\mathrm{Ru}(\mathrm{bpy})_{3}\right]^{2+}$ complex, as shown in Fig. 4. In structure (a) in Fig. 4, the molecular plane of one of the bipyridine ligands of the $\left[\mathrm{Ru}(\mathrm{bpy})_{3}\right]^{2+}$ complex, which locates in the minor groove, lie perpendicular with respect to the DNA helical axis, with the other two ligands directly outside the minor groove. Although this structure deviates from the $\mathrm{LD}^{\mathrm{r}}$ experimental results that the molecular plane of any bipyridine ligand cannot be perpendicular, it was included in the calculation as this structure is conventional and occasionally observed from other related $\mathrm{Ru}(\mathrm{II})$ complexes. In structure (b), the molecular plane of one of the bipyridine ligands lie along the minor groove, hence resulting in a $45^{\circ}$ orientation with respect to the DNA helical axis. Finally, in structure (c), the two bipyridine ligands wrap around the phosphate groups of the DNA and interact electrostatically. In the case of the $\left[R u(t p y)_{2}\right]^{2+}$ complex, however, the structure (b) type of binding mode is not possible because of the steric hindrance from the terpyridine molecular structure. The molecular planes of the pyridine in the terpyridine ligand cannot be in the same plane and are thus too bulky to be fitted in the narrow minor groove. Therefore, only two structures resemble structures (a) and (c) of the $\left[\mathrm{Ru}(\mathrm{bpy})_{3}\right]^{2+}$ complex, name- 
ly structures (d) and (e), and as such were involved in the energy calculations. Respective energy minimizations, using the AMBER Force Field, appeared to be $-8924.37,-9195.77$, and $-9145.22 \mathrm{kcal}$, suggesting structure (b) as the most preferred in the case of the $\left[\mathrm{Ru}(\mathrm{bpy})_{3}\right]^{2+}$ complex. Correlating with the experimental results, the highest energy was for structure (a). In the case of the $\left[\mathrm{Ru}(\mathrm{tpy})_{2}\right]^{2+}$ complex, the two energies of -8899.36 and $-9134.11 \mathrm{kcal}$ were obtained for structures (d) and (e), respectively. Therefore, it is conceivable that the two terpyridine ligands wrap around the DNA phosphate groups via electrostatic interactions when the $\left[\mathrm{Ru}(\mathrm{tpy})_{2}\right]^{2+}$ complex, forming adducts with DNA.

\section{Conclusions}

Both the $\left[\mathrm{Ru}(\mathrm{bpy})_{3}\right]^{2+}$ and $\left[\mathrm{Ru}(\mathrm{tpy})_{2}\right]^{2+}$ complexes bind to DNA. In the $\left[\mathrm{Ru}(\mathrm{bpy})_{3}\right]^{2+}$ adduct, the molecular plane of the bipyridine conceivably lies along the DNA minor groove, while the $\left[\mathrm{Ru}(\mathrm{tpy})_{2}\right]^{2+}$ complex binds at the surface of DNA through contact with the phosphate groups.

Acknowledgments. Dr. Jang is grateful for the postdoctoral fellowship conferred by the Korea Research Foundation (Grant no. C00125, 2009).

\section{References}

1. Norden, B.; Lincoln, P; Akerman, B.; Truite, E. Metal Ions in Biophysical Systems; Sigel, H., Eds.; Marcel Dekker, Inc.: New York, 1996; $\mathrm{p} 177$

2. Dupureur, C. M.; Barton, J. K. Inorg. Chem. 1997, 36, 33.

3. Greguric, I.; Aldrich-Wright, J. R.; Collins, J. G. J. Am. Chem. Soc. 1997, 119, 3621

4. Nair, R. B.; Teng, E. S.; Kirkland, S. L.; Murphy, C. J. Inorg. Chem. 1998, 37, 139.

5. Liu, J. G.; Ye, B. H.; Li, H.; Ji, L. N.; Li, R. H.; Zhou, J. Y. J. Inorg. Biochem. 1999, 73, 117

6. Onfelt, B.; Gostring, L.; Lincoln, P.; Nordén, B.; Onfelt, A. Mutagenesis 2002, 17, 317 .

7. Xu, H.; Zheng, K. C.; Chen, Y.; Li, Y.Z.; Lin, L. J.; Li, H.; Zhang, P. X.; Ji, L. N. Dalton Trans. 2003, 2260.

8. Xu, H.; Zheng, K. C.; Deng, H.; Lin, L. J.; Zhang, Q. L.; Ji, L. N. New J. Chem. 2003, 2, 1255.

9. Xu, H.; Zheng, K. C.; Lin, L. J.; Li, H.; Gao, Y.; Ji, L. N. J. Inorg. Biochem. 2004, 98, 87.

10. Olofsson, J.; Onfelt, B.; Lincoln, P.; Nordén, B.; Matousek, P.; Parker, A.W.; Tuite, E. J . Inorg. Biochem. 2002, 91, 286.

11. Coates, C. G.; Olofsson, J.; Coletti, M.; McGarvey, J. J.; Onfelt, B.; Lincoln, P.; Nordén, B.; Tuite, E.; Matousek, P.; Parker, A.W. J.
Phys. Chem. B 2001, 105, 12653.

12. Onfelt, B.; Lincoln, P.; Nordén, B.; Baskin, J. S.; Zewail, A. H. Proc. Natl. Acad.Sc.i USA 2000, 97, 5708.

13. Gisselfalt, K.; Lincoln, P.; Nordén, B.; Jonsson, M. J. Phys. Chem. B 2000, 104, 3651 .

14. Lincoln, P.; Nordén, B. J. Phys. Chem. B 1998, 102, 9583.

15. Yang, G.; Wu, J. Z.; Wang, L.; Ji, L. N.; Tian, X. J. Inorg. Biochem. 1997, 66, 141

16. Xiong, Y.; He, X. F.; Zou, X. H.; Wu, J. Z.; Chen, X. M.; Ji, L. N.; Li, R. H.; Zhou, J. Y.; Yu, K. B. Dalton Trans. 1999, 19.

17. Scott, A. M.; Pyati, R. J. Phys. Chem. B 2001, 105, 9011.

18. Chao, H.; Li, R. H.; Jiang, C. W.; Li, H.; Ji, L. N.; Li, X. Y. J. Chem. Soc.,Dalton Trans. 2001, 1920

19. Ayers, T.; Caylor, N.; Ayers, G.; Godwin, C.; Hathcock, D. J.; Stuman, V.; Slattery, S. Inorg. Chim. Acta 2002, 328, 33.

20. Sens, C.; Rodriguez, M.; Romero, I.; Liobet, A. Inorg. Chem. 2003, 42,8385 .

21. Vaidyanathan, V. G.; Nair, B. U. Dalton Trans. 2005, 2842.

22. Kumar, C. V.; Asuncion, E. H. J. Am. Chem. Soc. 1993, 115, 8547.

23. Harriman, A.; Khatyr, A.; Ziessel, R. Dalton Trans. 2003, 2061.

24. León, C. P.; Kador, L.; Peng, B.; Thelakkat, M. J. Phys. Chem. B 2005, 109, 5783.

25. Donoghue, K. A.; Kelly, J. M.; Kruger, P. E. Dalton Trans. 2004, 13.

26. Wilhelmsson, L. M.; Westerlund, F.; Lincoln, P.; Nordén, B. J. Am. Chem. Soc. 2002, 124, 12092.

27. Nair, R. B.; Teng, E. S.; Kirkland, S. L.; Murphy, C. J. Inorg. Chem. 1998, 37, 139.

28. Grover, N.; Ciftan, S. A.; Thorp, H. H. Inorg. Chim. Acta 1995, $240,335$.

29. Gallori, E.; Vettori, C.; Alessio, E.; Vilchez, F. G.; Vilaplana, R. V.; Orioli, P.; Casini, A.; Messori, L. Arch. Biochem. Biophys. 2000, 376, 156.

30. Deng, H.; Cai, J.; Xu, H.; Zhang, H.; Ji, L. N. J. Chem. Soc., Dalton Trans. 2003, 325.

31. Yun, B. H.; Kim, J. O.; Lee, B. W.; Lincoln, P.; Norden, B.; Kim, J. -M.; Kim, S. K. J. Phys. Chem. B 2003, 107, 9858.

32. Satyanarayana, S.; Dabrowiak, J. C.; Chaires, J. B. Biochemistry 1992, 31, 9319.

33. Liu, J. G.; Zhang, Q. L.; Shi, X. F.; Ji, L. N. Inorg. Chem. 2001, 40, 5045.

34. Vos, J. G. Polyhedron 1992, 11, 2285.

35. Caspar, J. V.; Meyer, T. J. J. Am. Chem. Soc. 1983, 105, 5583.

36. Hirot, C.; Lincoln, P.; Nordén, B. J. Am. Chem. Soc. 1993, 115, 3448.

37. Constable, E. C.; Cargill Thompson, D. W.; Tocher, D. A.; Daniels, M. A. M. New J. Chem. 1992, 16, 855 .

38. Nordén, B.; Kubista, M.; Kurucsev, T. Q. Rev. Biophys. Chem. 1992, 25, 51 .

39. Nordén, B.; Kurucsev,T. J. Mol. Recognit. 1994, 7, 141.

40. Rodger, A.; Nordén, B. Oxford University Press: New York 1997.

41. Moon, J.-H.; Kim, S. K.; Sehlstedt, U.; Rodger, A.; Nordén, B. Biopolymers 1996, 38, 593. 